DOI: $10.15503 /$ jecs20152.20.32

\title{
A FORMER ROMANIAN SCIENTIFIC SOCIETY: THE SOCIETY OF PHYSICAL SCIENCES (1890-1910)
}

\author{
Iavorenciuc George Andrei \\ Babeş-Bolyai University, Faculty of History \\ Strada Mihail Kogălniceanu 1, Cluj-Napoca 400084, Romania \\ E-mail address: iavorenciuc.andrei@gmail.com
}

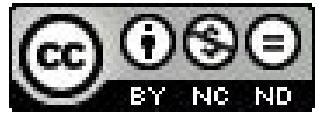

\begin{abstract}
The Society of Physical sciences (phisycs, chemistry and mineralogy) has been an important Romanian scientific society since its establishment, in 1890 until the middle of the twentieth century. This paper seeks to provide an analysis of its activity in the first two decades of existence, a less studied period, namely how its enterprises contributed to the dissemination and spread of the latest scientific ideas within Romania's culture. The society was founded at the initiative of some of the most proeminent Romanian scientists of that period and, until the end of the nineteenth century, it expanded its sphere of activity by including sections on mathemathics and natural history. Therefore, its activity, exemplified by public conferences, presentation of members' personal scientific endeavors, intellectual debates or scientific missions, reflected the general development of physical sciences in Romania in that epoch. This research is based mostly on a close scrutiny of society's scientific journal.

Keywords: Romania, science, scientific society, culture, 1890-1910
\end{abstract}

\section{INTRODUCTION}

"The society of physical sciences (physics, chemistry, mineralogy)" was constituted in the year 1890, in the broader context of the relative scientific development of the Romanian Kingdom. Romania was set in a modernization process, that had begun in the middle of the nineteenth century. Consequently, the country was attempting to develop a scientific life according to the contemporary exigencies. The universities and the affiliated laboratories, but also the Romanian Academy were the main exponents of the scientific life. At another level, there were the scientific societies; these represented different forms in which the scientists could work together than those previously stated, but with no less importance. In this respect, the activity of "The society of physical sciences" was significant: on one hand, it represented a model of scientific organization, which eased the cooperation of some of the most prominent Romanian scientists. From this point of view, we can consider the memoirs published in the society's scientific journal as representative for the level of scientific development of that epoch. On the other hand, the society was a medium which facilitated the transition of specialized scientific knowledge and abstract concepts from the academic milieu 
into the public space. Within this article, we shall analyze the society's activity, following these guidelines, in the first two decades of existence: 1890-1910. The society continued to function until 1949, but in an altered formula compared to the original one.

\section{THE ORGANIZATION}

The society was founded at the initiative of some of the most prestigious Romanian scientists and university teachers. Many of them were important public figures and some of them significant politicians. The most eloquent example is represented by the chemist Constantin Istrati (1850-1918), the leader of the society in all this period. He was more than once a minister in the Romanian government. At his initiative, some of the greatest scientists of the country, among them the physicist Emanoil Bacaloglu (1831-1891) and the chemists Alexe Marin (18141895) and Alfons Oscar Saligny (1853-1903), organized the society in april 1890.

The aim of it was, from the very beginning, to build up a framework in which the Roumanian researchers could have the possibility of working together, of presenting their original work in front of their colleagues and of publishing their findings in the pages of an international scientific journal. These purposes were enunciated by Constantin Istrati in the inaugural meeting. Accordingly, he pointed out that the number of Romanian chemists trained in Berlin or Paris had increased in those years and, for that reason, they all must join a scientific society, where they could benefit from their association. The objectives of the collaboration were dialogue, exchange of ideas and choice of subjects of study. Another aim was represented by the actualization of knowledge from the various scientific branches for the members themselves (Istrati, 1892a, p. 5). The number of chemists and physicists had attained, indeed, in the last decade of the nineteenth century a critical mass to enable their coagulation in a specialized institution. The same Constantin Istrati counted, in 1891, adjacent to the older science teachers: twelve graduates in physical sciences from universities in the country, sixteen graduates and twenty five science doctors from universities abroad, four graduates of polytechnic schools and other categories with a chemist's diploma or who worked as assistants in laboratories in the country (Istrati, 1892b, p. 87). Therefore there was a number of potential members for a scientific society who could publish original articles. However, their number increased in subsequent years.

Being thought of as a specialized society, whose aim was to gather the experts of the physical sciences, certain rules for accession to membership were established. In addition to the annual payment of a fee, the acceptance of a candidate had to be validated by a majority vote of the members. At the same time, the desiderata was to maintain a certain standard of the scientific activity. As a result, the most important decisions concerning the politics of society were taken by the society's committee. For this body were eligible only the society's members who had university diploma in physical, chemical, mathematical and natural sciences, diplomas issued by mining schools or polytechnics or those who had published 
original papers in the society's journal. Therefore the committee had the right to decide the communications to be published in the journal, research directions to be pursued by the society, the alteration of the statutes, or other administrative actions (Buletinul Societății, 1897a, pp. 13-16). As a result of these provisions, the society encompassed not only eminent scholars, scientists or academics, but also pharmacists, engineers, county teachers or students.

The biggest part of the society's activity was constituted from ordinary meetings. According to the regulation, there had to be held at least one meeting per month, but this provision was not always respected. At the meetings were presented original communications, followed by comments and discussions, essays that presented recent advances in sciences or presentations of the researches made by Romanian scientists abroad. As a norm of scientific conduct, the talking was permitted only on scientific issues discussed and at most twice on a topic, in a time frame of ten minutes (Buletinul Societății, 1892a, pp. 8-9). Consequently, interventions and the criticisms within the society meetings were brief and punctilious.

The organizational evolution of the society in the two decades studied reflects the tortuous process of institutionalization of scientific disciplines in Romania. It also shows the distance that existed between the scientific organization projects of some scholars and the possibilities of their implementation. Initially, on its inception, the society's leaders wanted it to be specialized only in the physical sciences, such as physics, chemistry and mineralogy. There were voices which proposed a wider field of activity by adding of the natural sciences like botany, zoology and geology. The reasons were the potentially increased number of members and the possible richer activity, but this proposal was not accepted (Buletinul Societății, 1892b, p. 6). As a result, the first name of the society was "The society of physical sciences (physics, chemistry and mineralogy)". However, in the coming years, inconveniences of this limitation of the activity field emerged. It was found that the number of scientists who were able to constantly contribute with original researches in these areas was not enough. Therefore, the society enlarged its areas of activity and in 1897 merged with the "Societatea amicii ştiințelor matematice" ("The society of mathematical partners"). This included leading representatives in Romanian mathematics. Also in that year the decision was taken to create a section of natural sciences, which incorporated researches in geology, botany, zoology and agronomy. As a result, it changed its name to the "Society of Sciences from Bucharest"(Istrati, 1897a, p. 1). Although theoretically divided into sections, the meetings were united throughout the entire studied period. This shows that the full individualization and specialization of the scientific disciplines was not yet possible, because of the small number of professionals at that time. Achieving the goal of specialization and autonomization of society's scientific areas in independent sections with separate meetings would take place in 1915 and then in the interwar period.

Another modification of society's name occurred in 1902 when it changed it to "The Romanian Society of Sciences". This name reflected, in the opinion of the society's leaders, the national importance and prestige earned by it at the beginning of the twentieth century. 
One of the main reasons why the society was set up was the publication of a scientific journal which would contain original studies and the results of researches conducted in Romania. It had been published since 1892. It was sent to the learned societies worldwide, scientific journals and prestigious scientists, thus contributing to the integration of Romanian scientific life results in the international scientific circuit. For this reason, a large number of memoirs published in the journal had been written in foreign languages, such as French or German. In the first decade of existence, the majority of society's revenues, which were obtained mainly from membership fees, had been directed to the editing of the journal. But, with the growth of its prestige, the editing task was taken over by the Ministry of Public Instruction. So, starting from the year 1900, the government printed the journal in its own typography department, 1,000 copies for each edition (Angelescu, 1942, p. 30). Regarding the nature of the content, the society's leaders were aware that they could not edit a journal specialized in just one field of study, as were most of the scientific journals in the West. The reason was that, in Romania there was not a highly developed scientific press in which to publish high-level scientific studies from all areas of physical sciences (Buletinul Societății, 1892c, p.3). The content of the journal reflected these ideas, and, as a result, it comprised studies of all fields of sciences. Even under these conditions, in the early years of appearance, its content suffered because the number of those who could publish constantly original papers was not yet very high. In addition, there were researchers who were trying to publish their papers in foreign journals. For these reasons, in 1896 the editorial staff announced that all subscribers who passed their doctoral thesis in physical sciences or had made original research in these fields, should send them to the journal in order to be published (Buletinul Societătiii, 1896, copertă). In 1897 it published a notice to all the persons dealing with the sciences in the country to stop sending their papers abroad. Rather, those works should be referred to the society's journal (Buletinul Societătii, 1897b, p. 97). But, in time, the reputation of the journal advanced and the number of original studies published increased every year. As a result, an evaluation done in 1910 counted, on the 18 volumes previously published, 8162 pages which included 499 original works due to Romanian and foreign researchers. Also in that year, the journal was being sent to 122 scientific societies and foreign science journals (Istrati, 1910, pp. 240-242). The journal's pages were open to all original papers in the country. However, a mechanism existed, specific to all specialized scientific journals, through which was performed a selection of the memoirs that were to be published. Originally, the society's committee had this decision. After 1897, specialized editorial committees were established for every particular field: mathematics, physical sciences and natural sciences.

\section{THE ACTIVITY}

The society's scientific activity consisted in some collective enterprises and also, in the scientific memoirs published by its members. In the first category we can enumerate a program for the adoption of a uniform chemical terminology, 
zoological researches, or the attempt to change the official calendar of the country. The second category is composed of the great mass of specialized researches from mathematics, physics, chemistry, mineralogy, geology or zoology. All of these reflected the conceptual, methodological and factual development of Romanian science of that epoch.

The society was organised at the initiative of some chemists, in particular, and consisted of chemists, in a large proportion. Accordingly chemistry occupied a central place in the society's activity. One of the first issues addressed at the society's meetings was the nomenclature that was used in organic chemistry. In order to create a rational and universal chemical nomenclature, international debates between chemists were organised from the middle of the nineteenth century (Bensaude-Vincent, 2008, p. 181). These meetings had multiplied at the end of it. The most important moments of this collective work were the International Conference of Chemistry held in Paris in 1889 and, especially the international conference on chemical nomenclature held in Geneva in 1892 (Bensaude-Vincent, 2008, pp. 186-187). This program of creating a standardized universal nomenclature was an example of international collaboration in science at that time. In this effort, chemists from Romania participated as well, by presence at congresses, meetings and writing of reports or working drafts.

Urged on by this international effervescence but also to meet a national urgency, the society's secretary, Constantin Istrati, proposed in 1890 the adoption of a Romanian chemical nomenclature, to serve as the norm in the society's publications (Istrati, 1892c, p. 25). In the committee appointed to decide the matter were named the chemists that had edited the first Romanian chemistry textbooks. So, they were familiarized with the terminological issues. Adopting a common Romanian chemical nomenclature was a necessity: many of the Romanian chemists had studied in Germany or in France and usually used different notations, specific to the academic standards adopted there. This, in turn, led to serious difficulties in the communication of results. Therefore, the aim was to adopt a common notation with which to publish all works of chemistry in the country (Buletinul Societății, 1982d, pp. 222-223). This program represented a first general effort to professionalize the work of the national community of chemists by imposing common standards of communication and realization of their activity. In the coming years it was adopted as the nomenclature proposed by the Congress of Geneva. The society's journal popularized this nomenclature by publishing in its pages the rules and examples that formulated it.

Another program initiated by the society was the inventory of the country's zoological species. The inclusion of the natural sciences within the society's interests had beneficial effects for the enrichment of their content. An example in this respect was zoology. The core components of this science consisted in identifying species in a given area followed by their classification. The effort invested in these activities was immense. New scientifically viable data could been obtained only after a collective collaboration, the kind that could take place in a scientific institution. Therefore, since 1897 efforts were made to identify and to collect the zoological wildlife, followed by its classification. The studies conducted by the society were 
not the only zoological studies in Romania of that epoch. Nevertheless, very abundant material was gathered within its journal. The impetus for this action was given in 1897 by the French naturalist, elected member, Maurice Jaquet. He proposed a comprehensive program of study with the aim to edit as complete as possible „Romania's Fauna". In the proposal to the society's office, Jaquet noted that the Romania's fauna was little known and that apart from a few isolated works, nothing serious had been done (Jaquet, 1897, p. 120). The French naturalist wanted that his plan be deployed by Romanian society, the main reason being that at its realization it could also contribute other Romanian or foreign naturalists work. For the effective support of this action, the society ordered the allocation of financial funds to Jaquet (Buletinul Societății, 1898a, p. 219). In addition, some of the most important Roumanian biologists and zoologists of that period agreed to participate in this joint project. Some of them had already begun to do studies on this topic. They were: Grigore Antipa, director of the Museum of Natural History, Dimitrie Voinov, Nicolae Leon, Ion P. Licherdopol, Arnold-Lucien Montandon and Paul Bujor (Istrati, 1897b, p. 108). Another source of knowledge about the Romanian fauna was represented by studies that had classified species harvested by members of "the naturalists society", one wich was consisted of professionals and also amateurs. It organized scientific trips after 1898 (Zottu, 1903, p. 140).

The content and nature of the vast majority of scientific studies conducted in the two decades may be placed in what Thomas Kuhn defined as ",normal science" (Kuhn, 1996). The inventory of the natural elements (either rocks, plants or chemical elements), the analyses, the interpretations from the various scientific fields pursued by the society, were made under the generally accepted theoretical models, the paradigms. Therefore, the scientists tried to find new facts, to make additions or to nuance them. They never proposed revolutionary theories or interpretations fundamentally different from those commonly shared at the time. In this respect the nature of the research could be characterized as cumulative.

Regarding physics, the classical mechanistic paradigm of the nineteenth century was not seriously questioned, although the period that we study coincided with what was retrospectively identified as ,a crisis of modern physics" (1895-1905) (Hobsbawm, 1989, pp.247-249). Rather, the tendency was to try to explain and integrate the new discoveries, such as X-rays, in the traditional theoretical patterns. Atomic theory was tacitly accepted, although it was recognized that the existence of atoms was not yet positively demonstrated. This conclusion was attained rather by inference, because the atom's existence was considered a necessity for the development of certain theories of physics. Among other characteristics, the atom, as the ultimate component of reality, was characterized by: impenetrability, indivisibility, immutability and eternity (Istrati, 1896, p. 81). It's existence, thus, underlied the materialistic scientific perspective of nature.

The activity in this area consisted of the publication of the results obtained in physics labs in the country on caloric, electromagnetic or optical phenomena. At the same time, scientific demonstrations took place within society meetings, which allowed the audience to better understand the abstract and specialized concepts. An example was the presentation of a device for measuring the speed of sound in 
liquids (Buletinul Societății, 1907, pp. 109-110). On this chapter, the contributions due to the physicist Dragomir Hurmuzescu must be highlighted. After the epochal discovery of X-rays in 1895, Hurmuzescu was the one who familiarized Romanian scientists with this discovery. He did this in a conference held at a meeting of the society in 1896 and in a series of scientific memoirs sent to the journal between 1896-1897. It also must be highlighted that his work consisted in original research in this field, and not in a popularization activity.

"The earth sciences" like geology and the mineralogy were central fields of investigation for Romanian researchers in that period. The reasons were both the intrinsic value of the information obtained in the investigations, and also their potential economic value.

Geological studies have generally followed the nineteenth century norms of this science: the research on the form and structure of the great associations of rocks that forms the earth's crust and the attempt to compose a picture of their transformation in space and time. By highlighting new layers of rocks and sediments a more detailed knowledge of the country's natural elements was pursued. The petrographic and comparative analysis was intended to insert this data into a broader theoretical model, in order to help understanding their evolution. Stratigraphy and paleontology were the basic tools of those enterprises.

Mineralogical research consisted in analyzing and classifying the previously collected mineralogical collections which were deposited in various museums or laboratories. The stimulant in this regard came from a member of the society, the geologist Vasile Butureanu. He published one of the first studies in the country which explained the method for classification of minerals. His specific purpose was to help other researchers or enthusiasts to determine and classify the collections they owned (Butureanu, 1894, p. 271). Other research in these areas focused on presenting specific mineralogical species of Romania.

As regards the economic side of this science, the editorial staff wanted a special section about "petroleum" in the journal. They considered that this industry was a part of chemistry and that the scientific articles published could contribute to its development (Buletinul Societății, 1893b, pp. 184-185). As a result, over the years several analyses regarding the quality and location of petrol in Romania were published.

During this period, analytical studies on this subject had accumulated, giving the chance to some researchers to propose general explanations about the genesis of the oil. That problem had not been solved at that time. Therefore, the geologist Ludovic Mrazec presented the arguments for the theory of animal and vegetable origin of oil. Thus, he dismissed the theory of inorganic origin, supported by some foreign and Romanian scholars (Mrazec, 1905, pp. 254-257).

Another aspect of the society's activity was represented by its intention to study scientific issues of public interest or of those that were considered important for the country. At that time, scientists were trying to promote in the Romanian public sphere the link between science and industry and implicitly the link between science and economic development. For these reasons, areas of interest to them were the study of the country's natural resources or visitation of various factories, in order to streamline them (Buletinul Societății, 1893a, pp. 21- 22). 
In other memoirs, the scientific analysis expanded towards aspects of social life. Romanian scientists perceived their role in society as a civilizing and a pedagogical one. They considered themselves the owners of the absolute scientific method and of the knowledge with which to tackle all problems rationally. Therefore, they thought they could provide solutions even for the great social problems that had accompanied the modernization of Romania. So, they confronted some of the major social obsessions that existed in Romania at that time: alcoholism and the peasants' nourishment. For example, the chemist and the mineralogist Vasile Buțureanu wanted to use the scientific method, in this case the chemical analysis, to study the quality of alcohol which existed in Romania. His aim was to discover "the true cause of alcoholism" in the country. The problem was stringent, since alcohol was the cause, in his opinion, for "the darkest poverty, mental and nervous sicknesses, pellagra, madness, suicide and even death". This assumption was reinforced by the conclusions of his study which showed that from the 282 samples of alcohol studied during the year 1893 only 33 had optimal consumption conditions (Buțureanu, 1893, pp. 195-203). According to the historian Constantin Bărbulescu, the image that the intellectual elite of that time had built about the peasants and their habits was not entirely consistent with reality. This image was the result, apart from direct observations, of the prejudices and the mental contortions due to the different cultural end educational backgrounds shared by the elite (Bărbulescu, 2015). Of this mind was somewhat conscious the chemist Popovici-Lupa, who criticized the assertion that "the Romanian peasant feeds very bad". This allegation was shared as a dogma by the whole intellectual elite, including by the scientists, without making any effort to objectively discuss its scientific value. As a result, he believed that the problem could only be solved by experimental method. Therefore, he conducted a series of observations that measured the behavior of a subject fed with peasant's food and especially with corn. He concluded that ,the vegetarian diet, based essentially on corn and bread, is sufficient to meet the needs of the body". He thought accordingly that he had proven his colleagues wrong, due to his method (Popovici-Lupa, 1905, pp. 86113). However, these issues, nutrition and alcoholism, were a reality in Romania at that epoch. But both belonged only to a little extent to the scientific registry, and in a much larger extent to a broader social one. The belief that any of them could be solved through scientific methods shows the growing prestige enjoyed by science at the time, and also the role that scientists had claimed in society.

As a scientific society comprised of individuals with prestige in Romanian culture, who wanted to influence the modernization and westernization of the country, it seriously debated and proposed the change of the Romanian calendar. It campaigned therefore to modify the Julian calendar with the Gregorian one. The issue of calendar modification had began seriously to preoccupy Romanian society at the end of the nineteenth century. Then, some intellectuals and scientists had considered that the time gap could represent an obstacle to integration in Western civilization. Therefore adoption of the Gregorian calendar was seen as a symbolic step whereby Romania would synchronize with the West, leaving behind the Oriental legacy. On a more pragmatic level, this action was 
considered a necessity imposed by the requirements of modern life, in which international relations were becoming increasingly important. An obstacle for the achievement of this reform was represented by the conservative position of the Romanian Orthodox Church.

The proposal for the change was first made public in a meeting held on 12/24 January 1898, when a committee was appointed to draft a bill to reform the calendar. The representative personalities of the committee were two of the first Romanian mathematicians who had obtained their doctoral degrees in the West, with theses of celestial mechanics: Spiru Haret, who was also an influential politician, and Nicolae Coculescu (Buletinul Societății, 1898b, p. 5). Due to their technical training, the society considered that it was entitled to claim a position of authority in this matter. Although the committee met and discussed, it did not made a decision for two years. At the end of 1899, the matter was again brought to the fore by the engineer and mathematician Ermil Pangrati. His main reason was that, with the turn of the century, the gap between the two calendars would increase from 12 to 13 days. He further demanded that any theological issue to be left out of this discussion and to focus on the benefits that this adjustment would bring in practical life, specifically in administration, communication, transport and economy (Buletinul Societății, 1900a, pp. 3-6). He also emphasized that the unification of calendars was required by modern life demands, in which the standardization of measures and international trade started to have an increasingly higher role (Buletinul Societătii, 1900b, pp. 13-19). Following these interventions, the responsible committee for studying the problem drafted a bill in the first month of 1900. The draft law was simple in reasoning and did not required complex calculations to substantiate it. The society's members renounced the idea, advanced by some researchers, of finding a compromise between the two calendars by creating an entirely new one, to reflect the exact astronomical reality. Thus, the enumeration of the great scientists' names as the law initiators, had more a symbolic role: to show the categorical option of the scientists. The draft law stipulated a simple conversion to the Gregorian calendar from that year, 1900. In the case of religious holidays it proposed that they would be celebrated on the days ordained by the Church (Buletinul Societății, 1900b, pp. 18-19). Despite the names and the reasons of those who proposed it, the law was not promulgated. The transition to the Gregorian calendar would be made only in the year 1919.

\section{THE PHILOSOPHY}

The conferences, the discourses and some of the scientific memoirs represented occasions for the Romanian scientists to develop their philosophical concepts and to argue the role of science in Romania. By these means, the society was a source of dissemination of the positivist ideas and of a rationalist attitude within Romania's culture.

The Romanian scientists considered that the spirit of time was characterized mainly by positive science. Due to its use, man had discovered and studied 
almost all of nature's secrets. Science had attained in the nineteenth century an unprecedented development, incomparable with that of the previous centuries. This development was more visible in the physical sciences and especially in chemistry. Its practitioners had even transformed, from mere observers of nature, to creators, because of the syntheses of organic chemistry (Istrati, 1901, pp. 3-13).

Constantin Istrati concluded after he analysed the atomic structure of the universe and the eternal transformation of its elements from simple to complex that "the main characteristic of life and thought is its continuous evolution for the better" (Istrati, 1896, p.80). He thus justified the general optimism that characterized "La Belle Époque" in the laws of nature.

The philosopher and physicist Ştefan Michăilescu pointed out that the basis of the natural philosophy at that time consisted of the mechanical theory of the universe, which was based on the laws of thermodynamics. The laws demonstrated that the cosmos was made only of matter and movement always in transformation. Knowledge of these laws, due to modern science, had enabled the scientists to manipulate the comprehensible properties of matter, and to put them, in this way, into the service of humanity (Michăilescu, 1897, p. 495).

This confidence in science and progress delineated a certain social philosophy. Its main element was the belief that the advancement of science makes people live an increasingly moral life (Istrati, 1901, p. 23). Accordingly, the scientist attained a special place in society: to be a moral guide. Scientists had even claimed that by the work they were doing, in the scientific research, which was conducted mainly for the public interest, that they had offered the example of the proper life of modern times. That was characterized by a moral, peaceful, useful and happy existence (Buletinul Societății, 1903, p. 175).

Regarding the relationship between science and religion, it was touched upon directly in a few discourses and memoirs. There were scientists who believed that religion and science, far from being excluded, were rather complementary activities. A proof of this belief was the proposal that the committee which debated the modification of the calendar should include two professors from the faculty of theology, so that the chosen solution would satisfy the Church (Buletinul Societătiii, 1898c, pp. 117-118). However, most scientists adopted philosophical and scientific conceptions incompatible with Orthodox Christianity: the belief that the earth's age is a few million years, the evolution of species and of humans, explanation of the phenomena of nature only through transformation of matter, science as the foundation of morality.

Thus, the society was a center for the dissemination of new ideas and of a scientific spirit within Romanian culture. It proposed the image of a rational, mechanical and deterministic universe, and a representation of science as the driving force of progress, including for the Romanian civilization. Consequently, although the society was not aimed at popularizing science, it represented however a medium through which many of the ideas and concepts of academic science could enter the public space. 


\section{CONCLUSIONS}

The evolution and activity of the "Society of Physical Sciences" was symptomatic for the level of organization and scientific life of Romania during 1890-1910. It was conceived as a specialized society, which gathered together in an institutional setting all practitioners of physical sciences, either consecrated scientists or novices. In time, it incorporated into its areas of activity mathematics and the natural sciences. By this means, all the physical and natural sciences could benefit from the society's institutional support. The support consisted mainly in the ability to publish in the society's journal, one that was integrated into the international scientific circuit. The scientific activity consisted both in initiating certain research programs, such as the imposition of a uniform chemical nomenclature or the inventory of Romanian fauna, and also in scientific memoirs of its members. As a result, the large number of specialized studies in physics, chemistry, geology, mineralogy and biology reflected the scientific norms of the era. On another level, the society's members, as representatives of a science that was at its prestigious peak at that epoch, wanted to address some of the country's social problems. Following the same logic, they also developed a public discourse on the importance of science for Romanian culture, and of the worldview that resulted from the great scientific discoveries. However, the society had been somewhat overshadowed in the public life of the country. The reason was that scientific activity did not have a special symbolic status in Romanian society, as culture, religion or the politics had. For this reason, it did not receive any special attention from historians.

\section{REFERENCES}

Angelescu, B. (1942). Societatea română de ştiințe. 50 de ani de activitate 1890-1940 [The Romanian Society of sciences. 50 years of activity 1890-1940]. București: Imprimeria Statului.

Bărbulescu, C. (2015). România medicilor. Medici, țărani şi igienă rurală în România de la 1860 la 1910 [The physicians' Romania. Doctors, peasants and rural hygiene in Romania from 1860 to 1910]. Bucureşti: Humanitas.

Bensaude-Vincent, B. (2008). Languages in chemistry. In: M. J. Nye (Ed.), The Cambridge history of science: The modern physical and mathematical sciences V (pp.174-190). Cambridge: Cambridge University Press.

Buletinul Societății [The Society's Journal] (1892a). Statutele Societătii de Sciinte Fizice din București [The statutes of the Society of Physical Sciences from Bucharest]. Buletinul Societății de Sciințe fizice (Fizica, chimia şi mineralogia) din Bucureşti-România, I, 8-9.

Buletinul Societății [The Society's Journal] (1892b). Proces verbal al şedinței a 2-a Societății de sciințe fisice [Record of the second meeting of the Society of Physical Sciences]. Buletinul Societătiide Sciințe fizice (Fizica, chimia şi mineralogia) din Bucureşti-România, I, 6-7.

Buletinul Societății [The Society's Journal] (1892c). făra titlu [article without title]. Buletinul Societății de Sciințe fizice (Fizica, chimia şi mineralogia) din Bucureşti-România, I, 1-3.

Buletinul Societății [The Society's Journal] (1892d). Propunerea făcută de d-l dr. Istrati relativ la nomenclatura română în chimie, în şedința de la 2/14 decembrie 1891[The proposal made by dr. Istrati relative to the Romanian nomenclature of chemistry in the meeting held on 2/14 December 1891]. Buletinul Societății de Sciințe fizice (Fizica, chimia şi mineralogia) din Bucureşti-România, I, 222-223.

Buletinul Societății [The Society's Journal] (1893a). Proces-verbal al şedinței a XXVI a societății de sciințe fizice [Record of the XXVI ${ }^{\text {th }}$ meeting of the Society of Physical Sciences]. Buletinul Societății de Sciințe fizice (Fizica, chimia şi mineralogia) din Bucureşti-România, I, 1-3. 
Buletinul Societății [The Society's Journal] (1893b). Dări de seamă relative la petroleu [Accounts related to petroleum]. Buletinul Societății de Sciințe fizice (Fizica, chimia şi mineralogia) din Bucureşti-România, II, 184-185.

Buletinul Societății [The Society's Journal] (1896). Anunț [Announcement]. Buletinul Societății de Sciințe fizice (Fizica, chimia şi mineralogia) din Bucureşti-România, $V$, (on the cover of the journal, no page).

Buletinul Societății [The Society's Journal] (1897a). Statutele Societății de Sciințe Fizice [The statutes of the Society of Physical Sciences]. Buletinul Societății de Sciințe din Bucuresci-România,VI, 13-16.

Buletinul Societății [The Society's Journal] (1897b). Corespondență [Mail]. Buletinul Societății de Sciințe din Bucuresci-România,VI, 97-98.

Buletinul Societății [The Society's Journal] (1898a). Proces verbal al şedinței de la 30 martie 1898 [Record of the meeting held on 30 march 1898]. Buletinul Societătii de Sciințe din Bucuresci-România, VII, 218-219.

Buletinul Societății [The Society's Journal] (1898b). Proces-verbal al şedintei de la 12/24 ianuarie 1898 [Record of the meeting held on 12/24 january 1898]. Buletinul Societății de Sciințe din BucuresciRomânia, VII, 5-6.

Buletinul Societății [The Society's Journal] (1898c). Proces-verbal al şedinței de la 2 Februarie 1898 [Record of the meeting held on second february 1898]. Buletinul Societății de Sciințe din BucuresciRomânia, VII, 117-118.

Buletinul Societății [The Society's Journal] (1900a). Proces verbal al şedinței de la 15 Noembrie [Record of the meeting held on 15 November]. Buletinul Societății de Sciințe din Bucuresci-România, IX, 3-6.

Buletinul Societătii [The Society's Journal] (1900b). Proiect de lege pentru introducerea calendarului apusan drept calendar al statului în viata civilă [Draft law regarding the introduction of the

western calendar as state's civil calendar]. Buletinul Societății de Sciințe din Bucuresci-România, IX, 13-19.

Buletinul Societății [The Society's Journal] (1903). Discurs [Discourse]. Buletinul Societății deSciințe din Bucuresci-România, XII, 169-175.

Buletinul Societătii [The Society's Journal] (1907). Proces-Verbal al şedintei dela 5 Martie 1907 [Record of the meeting held on 5 March 1907]. Buletinul Societății de Sciințe din Bucuresci-România, XVI, 109-111. Buțureanu, V.C. (1893). Cercetări asupra alcoolurilor în România [Research on the alcohol in Romania].

Buletinul Societății de Sciințe fizice (Fizica, chimia şi mineralogia) din Bucureşti-România, II,

195-203.Buțureanu, V.C. (1894). Studii cristalografice, chimice şi optice asupra colecțiunei de minerale şi roci a Laboratorului de Mineralogie şi Petrografie a Universității din Iaşi [Crystallographic, chemical

and optical studies on the minerals and rocks collection of the Mineralogical and Petrographic

Laboratory of Iaşi's University]. Buletinul Societății de Sciințe fizice (Fizica, chimia şi mineralogia) din București-România, III, 271-280.

Hobsbawm, E. J. (1989). The age of empire 1875-1914. New York: Vintage Books.

Istrati, C. (1892a). Cuvântarea d-lui dr. Istrati, în şedinta de la 24 Martie (5 aprilie) 1890 [The speech of dr. Istrati at the meeting held on 24 march (5 april) 1890]. Buletinul Societății de Sciințe fizice (Fizica, chimia şi mineralogia) din Bucureşti-România, I , 4-6.

Istrati, C. (1892b). Cuvântarea d-lui dr. Istrati cu ocazia aniversărei primului an de la înființarea Societății de Sciințe fizice, în şedința de la 24 Martie (5 aprilie) 1891 [The speech of dr. Istrati on the first anniversary from the founding of the Society of Physical sciences, at the meeting held on 24 March (5 April) 1891]. Buletinul Societății de Sciințe fizice(Fizica, chimia şi mineralogia) din Bucureşti-România, I (3), 82-111.

Istrati, C. (1892c). Nomenclatura în chimia organică [The nomenclature in organic chemistry]. Buletinul Societătii de Sciinte fizice (Fizica, chimia și mineralogia) din București-România, I(1), 25-31.

Istrati, C. (1897a). Inainte-cuvântare [Speech]. Buletinul Societății de Sciințe din Bucuresci-România. VI (1), 1. Istrati, C. (1897b). Dare de seamă despre mersul Societătii în decursul anului 1896-97 [Account on the evolution of Society during the year 1896-97]. Buletinul Societății de Sciințe din Bucuresci-România, VI, 102-109.

Istrati, C. (1896). Unitatea materiei (conferință) [The unity of matter (conference)]. Buletinul Societății de Sciințe fizice (Fizica, chimia şi mineralogia) din Bucureşti-România, V, 79-84.

Istrati, C.I. (1901). Discours prononcé par M. le Dr. C.I. Istrati sécrétaire général a le 15(28) Janvier 1901, à l'occasion de la première séance du 20-ème siècle [Discourse held by the general secretary Dr. C.I. Istrati on 15(28) January, on the occasion of the first meeting of the XXth century]. Buletinul Societății de Sciințedin Bucuresci-România, X, 3-36. 
Istrati, C.I. (1910). Societatea română de sciințe. Darea de seamă cu ocaziunea aniversărei sale de 20 ani în ziua de 28 martie/ 10 aprilie 1910 [The Romanian society of sciences. Account on the occasion of its 20th anniversary held on 28 march/ 10 april, 1910]. Buletinul Societătii de Sciințe din BucuresciRomânia, XIX, 224-263.

Jaquet, M. (1897). Proposiția făcută de d-1 Jaquet în şedința de la 10/22 februarie relativă la studiul faunei

din România [The proposal made by mr. Jaquet in the meeting held on 10/22 february regarding the research of the Romanian fauna]. Buletinul Societății de Sciințe din Bucuresci-România, VI, 121-123.

Kuhn, T. S. (1996). The structure of scientific revolutions (3rd ed.). Chicago: University of Chicago Press.

Michăilescu, Ş. C. (1897). Vertej cu abur. Nou motor rotativ cu dubla dentanta liberă [Swirl of steam. A new rotativ engine]. Buletinul Societății de Sciințe din Bucuresci-România, VI, 486-506.

Mrazec, L. (1905). Observațiuni asupra genesei petrolului având în vedere, în special, zăcămintele din România [Observations based especially on the Roumanian deposits regarding the genesis of petroleum] . Buletinul Societății de Sciințe din Bucuresci-România, XIV, 254-257.

Popovici-Lupa, N.O. (1905). O încercare asupra valorii alimentare a porumbului [An experiment on the food value of corn]. Buletinul Societătii de Sciințe din Bucuresci-România, XIV, 1905, 86-113.

Zottu, S.G. (1903). Liste des orthoptère récoltés en Roumanie par les membres de la société des naturalistes de Roumanie pendant les années 899-1902 déterminés par Stefan Gh. Zottu [List of orthoptera harvested in Romania by members of the Society of Naturalists from Romania during the years 1899-1902 determined by Stefan Gh. Zottu]. Buletinul Societății de Sciințe din Bucuresci-România, XII, 140-148. 